\title{
Diel Variation in the Structure of Seagrass- Associated Epibenthic Macroinvertebrate Communities
}

\author{
Holly S. Greening* and Robert J. Livingston \\ Department of Biological Science, Florida State University, Tallahassee, Florida 32306, USA
}

\begin{abstract}
Epibenthic macroinvertebrate community structure (species composition, numbers of individuals and species, and relative abundance distributions) were examined at 4 study sites in the northeast Gulf of Mexico (Apalachee Bay, Florida, USA). The relative abundance distribution changes with time of sampling (diurnal or nocturnal) because individual species become more or less numerically abundant in nocturnal samples. The number of individuals collected was significantly different between diurnal and nocturnal samples at 3 of the 4 study sites. The degree of day/night variation appears to be associated with habitat complexity (as defined by plant biomass and red algae volume) for number of individuals, but not for number of species, collected. The inadequacies and consequences of reliance on an exclusively diurnal epibenthic sampling program for a good representation of macroinvertebrate community structure are discussed.
\end{abstract}

\section{INTRODUCTION}

Field and laboratory studies show that many seagrass macroinvertebrates are primarily active at night taking refuge during daylight hours (Fuss 1964; Hobson 1965; Fuss and Ogren 1966; Hughes 1968; Segal 1970; Kikuchi and Pérès 1977; Reynolds and Casterlin 1979). Individuals taking diurnal refuge within the substrate or other protected areas are less likely to be collected by epibenthic sampling techniques. Unfortunately, most epibenthic sampling programs rely solely on daytime collections, and many of the descriptions (and resulting theories) concerning seagrass macroinvertebrate 'communities' (sensu Pielou, 1977) are based on such studies (Hoese and Jones, 1963; Dragovich and Kelly, 1964; Kikuchi, 1966; Hooks, 1973; Hooks et al., 1976; Livingston, 1976, 1977a; Brook, 1978; Dugan, 1980).

Several studies have indicated that reliance on diurnal sampling may produce a distorted view of macroinvertebrate community 'structure' (e. g. species composition, species number, and relative abundance distributions). In Panamanian seagrass meadows, for example, the number of individuals collected at night

\footnotetext{
- Present address: Institute of Ecology, University of Georgia, Athens, Georgia 30602, USA
}

was significantly larger than that taken during the day (Heck, 1977). The increase at night was the result of greater abundances of species that had been collected diurnally and the addition of species collected exclusively at night. Coral reefs, areas that appear barren of invertebrate populations during daylight hours, have been shown to support large numbers of individuals that emerge only after dark, including diurnally 'rare species that become abundant at night (Hobson, 1965 1973, 1975; Starck and Davis, 1966; Hobson and Chess 1976; Ebeling and Bray, 1976). Livingston (1976) describes differences among epibenthic invertebrate communities based on diurnal and nocturnal sampling in a soft-sediment estuary. Peak numbers of individuals generally occurred at night and some species were collected predominately or exclusively at night. Dugas (1975) described differences between diurnal and nocturnal trawl catches of fishes and invertebrates in Louisiana, and concluded that sampling designs that excluded either day or night catches could yield biased results

The present study was designed to investigate day/ night variation in number of species and individuals and relative abundance distributions of epibenthic macroinvertebrates in sub-tropical grassbeds of the northeastern Gulf of Mexico (Apalachee Bay, Florida, USA). In addition, the 4 stations examined (a dense 
grassbed, a red algae-grassbed area, a sparse grassbed, and an oyster shell-mud area) were chosen to determine the influence (if any) of differing degrees of habitat complexity both among stations and between the sampled day and night macroinvertebrate communities at each station.

\section{STUDY AREA}

Apalachee Bay is a shallow (1-3 $\mathrm{m}$ ) bay in the northeastern Gulf of Mexico (Fig. 1). Upland drainage systems include small rivers, marshes, swamps, and streams. The Econfina and Fenholloway Rivers, approximately $11 \mathrm{~km}$ apart, drain the same marshy

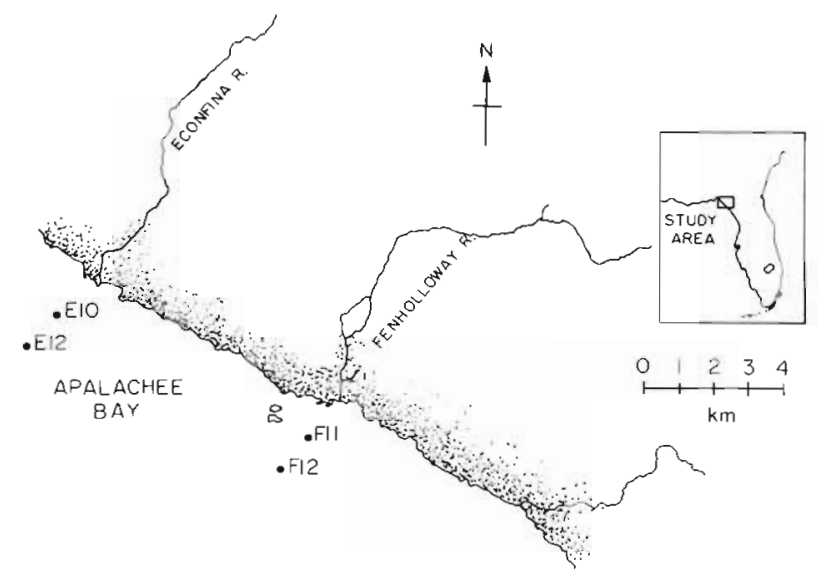

Fig. 1. Location of collecting stations; Apalachee Bay, Florida, USA

area and are very similar in terms of elevation, flow rate, sedimenary characteristics, and climatic features (Saville, 1966). Shallow oyster bars (dead and immature individuals) are located about $1.6 \mathrm{~km}$ south of the mouth of the Fenholloway River, extending $2-5 \mathrm{~km}$ southeast of the river. Scattered living oyster clusters are located south of the Econfina River mouth. A dense grassbed (primarily Thalassia testudinum, Syringodium filiforme, and Halodule wrightil) occurs offshore from the Econfina River. In the offshore Fenholloway area, plant biomass is lower than in the Econfina area (Zimmerman and Livingston, 1979; Livingston, 1980).

Since 1954, 100-220 million $\mathrm{l} \mathrm{d}^{-1}$ of kraft pulp-mill effluent (KME) have been released into the Fenholloway River. Associated high levels of nutrients, increased turbidity and color, and low dissolved oxygen in the Fenholloway system have resulted in greatly reduced biomass of benthic macrophytes ( $\mathrm{Zim}$ merman, 1974; Zimmerman and Livingston, 1976a, b, 1979). Hooks (1973), Heck (1973), and Hooks et al. (1976) found reduced dominance of invertebrate species in the Fenholloway drainage (compared with the unpolluted Econfina system), although there was no significant difference in the total number of species. Areas of chronic impact (up to $5 \mathrm{~km}$ offshore) also had reduced numbers of individuals of trawl susceptible fishes (Livingston, 1975).

In 1974, a major pollution abatement program was initiated by the pulp mill. Subsequent recovery studies (Livingston, 1977b, 1980, and unpubl. data) indicate improvements in water quality (turbidity, color, dissolved oxygen) relative to control areas (Econfina River estuary). Benthic macrophyte biomass in the Fenholloway system is presently below control levels, but new species have become established in recent years. Based on these findings, the pollution abatement program appears to have been partially successful. Present habitat differences are primarily due to the stage of recovery of seagrasses and their associated fauna (Livingston, 1980).

\section{MATERIALS AND METHODS}

Four permanently marked stations ( 2 in each drainage system) were sampled monthly by epibenthic crab scrape from January, 1978, through December, 1978 (Fig. 1). Eight replicate 1-min tows (determined to be adequate sample size by the species accumulation technique described by Livingston et al., 1976) were taken during the day (1300-1700 h) and at night (1 h after total darkness) at each station.

The epibenthic scrape consists of an $80 \mathrm{~cm}$ by $40 \mathrm{~cm}$ rigid metal frame secured to the cod (net) end of an otter trawl (6.3 mm mesh). When towed at approximately 2 knots, the heavy bottom bar rolls along the sediment or grasses where many invertebrates take refuge. Animals are scraped from the sediment or grasses and swept into the net. Invertebrates and fishes were sorted and preserved in $10 \%$ formalin and seawater in the field and identified, counted, sexed, and measured in the laboratory. Preliminary investigations indicate that the crab scrape is more effective (in terms of number of species and number of individuals taken) than an otter trawl in collecting epibenthic invertebrates (Leber and Greening, unpubl.).

Sampling stations have been described by Livingston (1975). Macrophyte collections were made monthly at all stations from 1973 to the present (Livingston, 1980). Water quality measures were taken at the time of sampling. Surface water samples were taken by hand, and bottom samples were taken with a 1-1 Kemmerer bottle. Water temperature was measured with a stick thermometer to the nearest one-half degree $C_{\text {, }}$ and salinity was determined with a temperature-compensated refractometer. Depth was determined with a sounding line. Secchi readings and color determinations were taken at each station. 
Sorenson's coefficient of community, CC (Pielou, 1977), is a useful measure of similarity if the data are qualitative. Sorensen's index (CC) is defined as

$$
C C=2 a /(2 a+b+c)
$$

where $a$ is the number of species common to the 2 samples concerned, and $b$ and $c$ are the number of species found only in the first and only in the second sample, respectively. $C C$ was calculated between the diurnal and nocturnal collections for each station. The degree of dominance ( $D I$ ) was determined by the dominance index of McNaughton (1968):

$$
D I=\left(n_{1}+n_{2}\right) / N
$$

where $n_{1}$ and $n_{2}$ are the absolute abundances of the first and second most numerous species and $N$ is the total number of individuals.

\section{RESULTS}

\section{Habitat Analysis}

Analysis of physico-chemical data indicates only slight differences between diurnal and nocturnal water temperatures at all stations. Salinity showed considerable diel variability, however, as a result of tidal effects and river flow, particularly at the inshore stations. Dissolved oxygen levels were never below
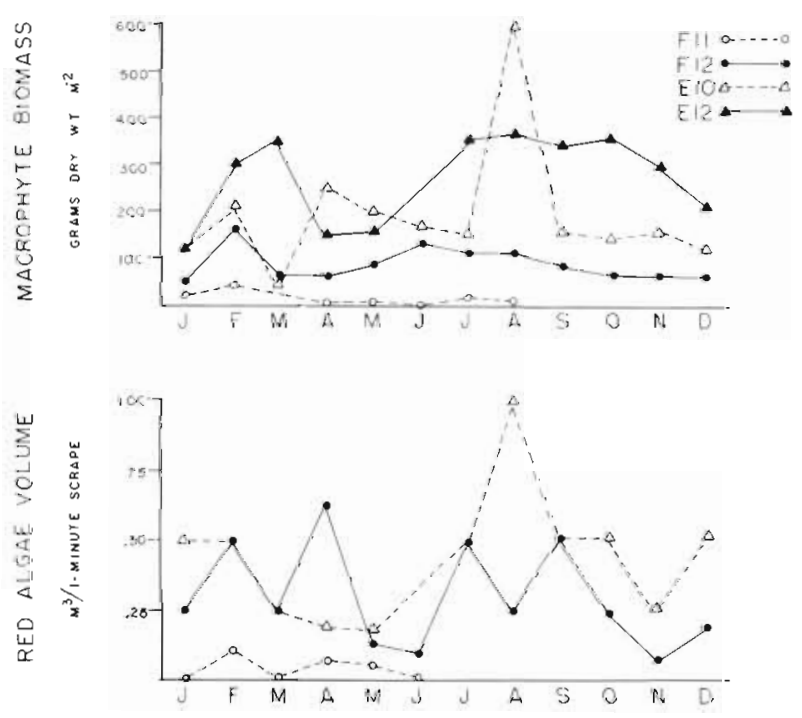

Fig. 2. Macrophyte biomass (g dry $\mathrm{wt}^{-2}$ ) and red algae volume $\left(\mathrm{m}^{3}\right.$ per $1-\mathrm{min}$ scrape tow) by station

$100 \%$ saturation. Color levels were generally higher in the Fenholloway than in the Econfina estuarine waters, which influenced the distribution and abundance of macrophytes (Zimmerman, 1974; Zimmerman and Livingston, 1976a, b, 1979; Livingston, 1980) Monthly variation of macrophyte standing crop over the study period is given in Fig. 2. Mean monthly standing crop values were as follows: F11, $8.31 \mathrm{~g}$ dry wt $\mathrm{m}^{-2} ; \mathrm{F} 12,100.84 \mathrm{~g}$ wt $\mathrm{m}^{-2} ; \mathrm{E} 10,201.11 \mathrm{~g}$ dry wt $\mathrm{m}^{-2} ; \mathrm{E} 12,272.20 \mathrm{~g}$ dry wt $\mathrm{m}^{-2}$

Sampling at Station F11 was discontinued after 7 mo because of the cumulative destructive effect of the crab scrape on the oyster shell-mud substrate at this station. Sixteen months of collections were made at Station E12.

\section{Relative Abundance}

The 5 most abundant macroinvertebrate species comprised $52 \%$ of the total number of individuals collected (Fig. 3). Relative dominance was low (Table 1), indicating a diverse system not numerically dominated by a small number of very abundant species. A total of 146,593 individuals and 95 species were collected at the 4 stations. Overall, 74,103 individuals (92 species) were taken at night, and 72,490 individuals (93 species) were collected during the day. There were no significant differences between diurnal and nocturnal species richness or numerical abundance ( $p<0.05$, Wilcoxon signed rank test). Sorensen's $C C$ was 0.89 between the day and night collections, indicating a high level of similarity. McNaughton's DI was higher in the day samples (Table 1). Fortyeight of the species collected $(50 \%)$ were crustaceans, $37(39 \%)$ were mollusks, and $9(9 \%)$ were echinoderms. Of those species comprising $\geq 0.1 \%$ of the total collection, 8 species were significantly more abundant during the day and 11 were more prevalent at night ( $p<0.05$, Wilcoxon signed rank test, Table 2 ). Fifteen species (of those comprising $>0.1 \%$ of the total collection) showed no significant differences in abundance between diurnal and nocturnal samples.

Despite gross similarities in the total number of species and individuals collected, diurnal and nocturnal samples provided contrasting views of the species composition and relative abundance distribution of epibenthic macaroinvertebrates within Apalachee Bay. Nine species $(9.4 \%$ of the total number of species collected) were found only in nocturnal samples, and 11 species ( $11.5 \%$ of the total number of species) were taken exclusively during the day. Furthermore, for many species, relative abundance within nocturnal collections appeared to be only weakly correlated with diurnal abundance (Fig. 4). Individual species thus made up a different proportion of the total catch within nocturnal versus diurnal samples, and the relative abundance distribution varied depending on the time of day at which a sample was taken. 


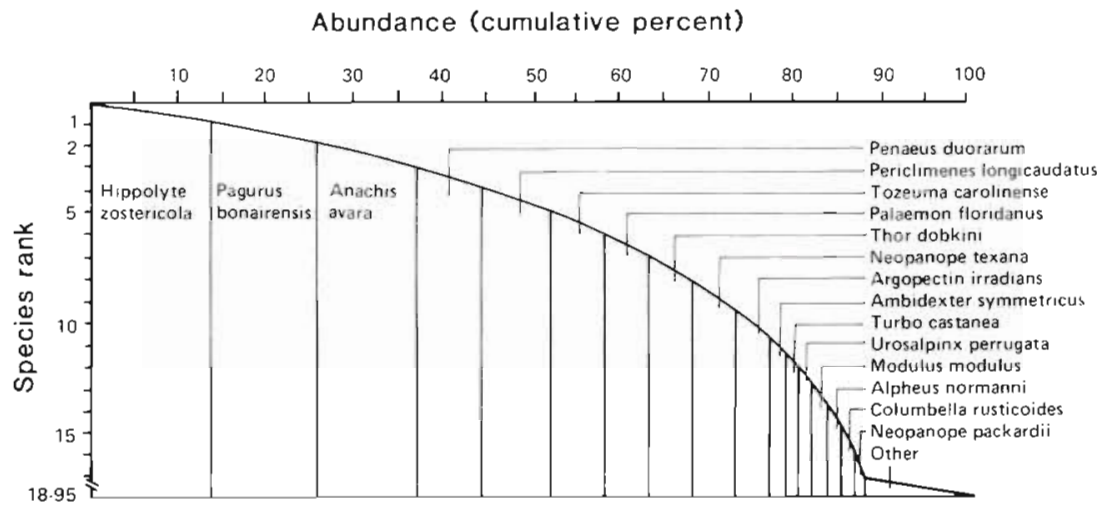

Fig. 3. Cumulative percent total abundance of animals. All stations, day and night combined

Of the 4 stations sampled, Fenholloway Station 11 (with lowest macrophyte biomass) had the lowest number of macroinvertebrate individuals collected in both day and night samples. Although there was no difference between the number of species taken diurnally (53) and nocturnally (52), a significantly higher number of individuals was taken at night $(\mathrm{p}<0.05$,

Table 1 Degree of dominance DI (McNaughton, 1968)

\begin{tabular}{|lccc|}
\hline & Day & Night & $\begin{array}{c}\text { Day/Night } \\
\text { combined }\end{array}$ \\
\hline All stations & .292 & .252 & .267 \\
F11 & .391 & .482 & .409 \\
F12 & .383 & .247 & .392 \\
E10 & .405 & .345 & .383 \\
E12 & .348 & .273 & .292 \\
\hline
\end{tabular}

Wilcoxon signed rank test; Fig. 5). Relative abundance within nocturnal and diurnal collections (Fig. 6) appeared to be correlated with the exception of Ambidexter symmetricus $(98.6 \%$ of this species was taken at night). Of the 4 stations sampled, Station F11 was the only station that had a higher degree of dominance at night (Table 1).

Station F12 had a sparse macrophyte standing crop and the second lowest number of macroinvertebrate individuals of the 4 stations sampled. There was no difference between the numbers of individuals (Fig. 5) or species taken in diurnal and nocturnal collections ( $p<0.05$, Wilcoxon signed rank test). The day/night similarity coefficient was 0.87 . However, day/night relative abundances of several species (Penaeus duorarum, Ambidexter symmetricus, Anachis avara) were not closely associated (Fig. 6).

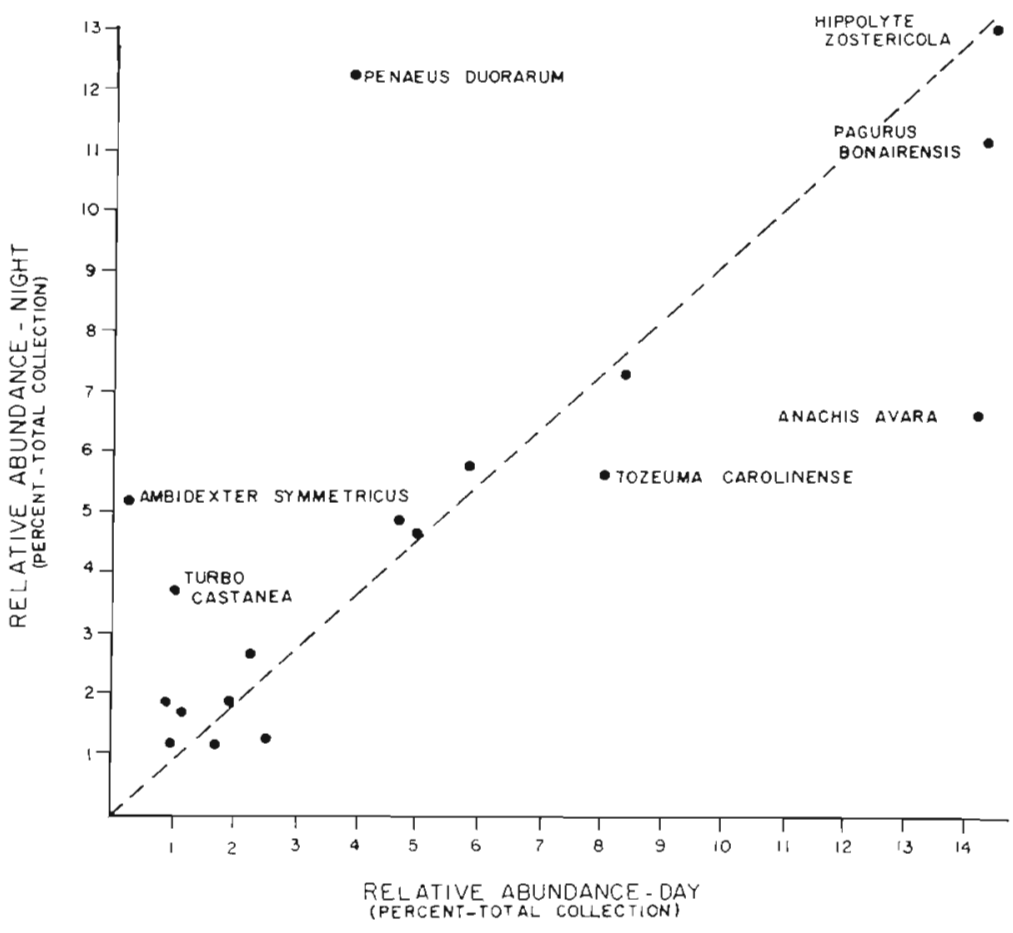

Fig. 4. Relative abundance day vs. night (summed over all dates) for those species comprising more than $1 \%$ of the total number of individuals collected. All stations combined. Dotted Iine: equal diurnal/nocturnal relative abundance 
Table 2. Overall macroinvertebrate abundance (combined stations and time) for those organisms contributing $\geq 0.10 \%$ to the total catch ${ }^{\circ}$ : Crustacea, E: Echinodermata, M: Mollusca. D/N: D = day catch significantly larger than night catch (No. of individuals), $\mathrm{p}<0.05$, Wicoxon signed rank $\mathrm{T}^{+}$statistic; $\mathrm{N}=$ night catch significantly larger than day catch; $0=$ no significant difference between day and night catches

\begin{tabular}{|c|c|c|c|c|c|}
\hline Rank & Genus and species & Phylum & $\mathrm{D} / \mathrm{N}$ & $\begin{array}{c}\text { No. of } \\
\text { individuals }\end{array}$ & $\begin{array}{c}\text { Percent } \\
\text { total catch }\end{array}$ \\
\hline 1 & Hippolyte zostericola & C & $\mathrm{D}$ & 20,526 & 14.00 \\
\hline 2 & Pagurus bonairensis & C & $\mathrm{D}$ & 18,558 & 12.66 \\
\hline 3 & Anachis avara & M & $\mathrm{D}$ & 15,200 & 10.37 \\
\hline 4 & Penaeus duorarum & $\mathrm{C}$ & $N$ & 11,636 & 7.94 \\
\hline 5 & Periclimenes longicaudatus & $\mathrm{C}$ & $\mathrm{D}$ & 11,548 & 7,88 \\
\hline 6 & Tozeuma carolinense & $\mathrm{C}$ & $\mathrm{D}$ & 10,007 & 6.83 \\
\hline 7 & Palaemon floridanus & $\mathrm{C}$ & $\mathrm{O}$ & 8,472 & 5.78 \\
\hline 8 & Thor dobkini & $\mathrm{C}$ & $\mathrm{O}$ & 6,981 & 4.76 \\
\hline 9 & Neopanope texana & $\mathrm{C}$ & $N$ & 6,951 & 4.74 \\
\hline 10 & Argopectin irradiens & M & $\mathrm{O}$ & 3,721 & 2.54 \\
\hline 11 & Ambidexter symmetricus & $\mathrm{C}$ & $N$ & 3,706 & 2.53 \\
\hline 12 & Turbo castanea & M & $\mathrm{N}$ & 3,467 & 2.37 \\
\hline 13 & Urosalpinx perrugata & M & $\mathrm{D}$ & 2,873 & 1.96 \\
\hline 14 & Modulus modulus & M & $\mathrm{O}$ & 2.710 & 1.85 \\
\hline 15 & Alpheus normanni & $\mathrm{C}$ & $N$ & 2,096 & 1.43 \\
\hline 16 & Columbella rusticaides & M & $\mathrm{D}$ & 2,095 & 1.43 \\
\hline 17 & Neopanope packardii & $\mathrm{C}$ & $\mathrm{N}$ & 2,049 & 1.40 \\
\hline 18 & Echinaster sp. & $E$ & 0 & 1,793 & 1.22 \\
\hline 19 & Libinia dubia & C & $\mathrm{O}$ & 1,583 & 1.08 \\
\hline 20 & Nassarius vibex & M & $\mathrm{O}$ & 1,554 & 1.06 \\
\hline 21 & Ophioderma brevispinum & $E$ & $\mathrm{D}$ & 1,464 & 1.00 \\
\hline 22 & Cerithium muscarum & M & $\mathrm{O}$ & 1,083 & 74 \\
\hline 23 & Latreutes fucorum & C & 0 & 785 & .54 \\
\hline 24 & Epialtus dilatatus & $\mathrm{C}$ & $\mathrm{O}$ & 637 & .43 \\
\hline 25 & Palaemonetes intermedius & $\mathrm{C}$ & $\mathrm{O}$ & 627 & .43 \\
\hline 26 & Prunum apicinum & M & $\mathrm{O}$ & 496 & .34 \\
\hline 27 & Ophiothrix angulata & $E$ & $\mathrm{O}$ & 415 & .28 \\
\hline 28 & Metaporaphis calcerata & $\mathrm{C}$ & $\mathrm{N}$ & 395 & .27 \\
\hline 29 & Podochela riisei & $\mathrm{C}$ & $\mathrm{O}$ & 383 & 26 \\
\hline 30 & Callinectes sapidus & $\mathrm{C}$ & $N$ & 366 & .25 \\
\hline 31 & Bulla striata & M & $N$ & 190 & 13 \\
\hline 32 & Portunus gibbesi & $\mathrm{C}$ & $N$ & 188 & 13 \\
\hline 33 & Sicyonia laevigata & $\mathrm{C}$ & $\mathrm{N}$ & 166 & 11 \\
\hline 34 & Pagurus pollicaris & C & $\mathrm{O}$ & 149 & .10 \\
\hline
\end{tabular}

Station E10 had identical numbers of macroinvertebrate species caught day and night (43), but significantly more individuals were collected in diurnal samples than at night $(p<0.05$, Wilcoxon signed rank test; Fig. 5), Unlike the other stations, relative abundances in diurnal and nocturnal samples appeared to be highly correlated (Fig. 6), with a day/night similarity coefficient of 0.85

Station E12 had the highest mean monthly macrophyte biomass of the four stations samples. Although there was no significant difference between total species richness during the day (60) and during the night (65), a significantly larger number of individuals was collected at night $(\mathrm{p}<0.05$, Wilcoxon signed rank test; Fig. 5). The coefficient of community $C C$ was 0.90 between day and night samples; however, for several species, relative abundance within diurnal collections was only weakly associated with nocturnal abundance (Fig. 6).

Crustaceans comprised $63 \%$ of those species representing $\geq 1 \%$ of the total number of individuals collected at the 4 stations, with mollusks and echinoderms contributing $30 \%$ and $7 \%$, respectively (Table 3 ). At 3 of the 4 stations (F11, F12, E12), more species of crustaceans were collected at night than during the day. Mollusk and echinoderm species were collected in approximately equal numbers day and night.

\section{DISCUSSION}

These data indicate that both diumal and nocturnal epibenthic sampling is needed for an adequate re- 


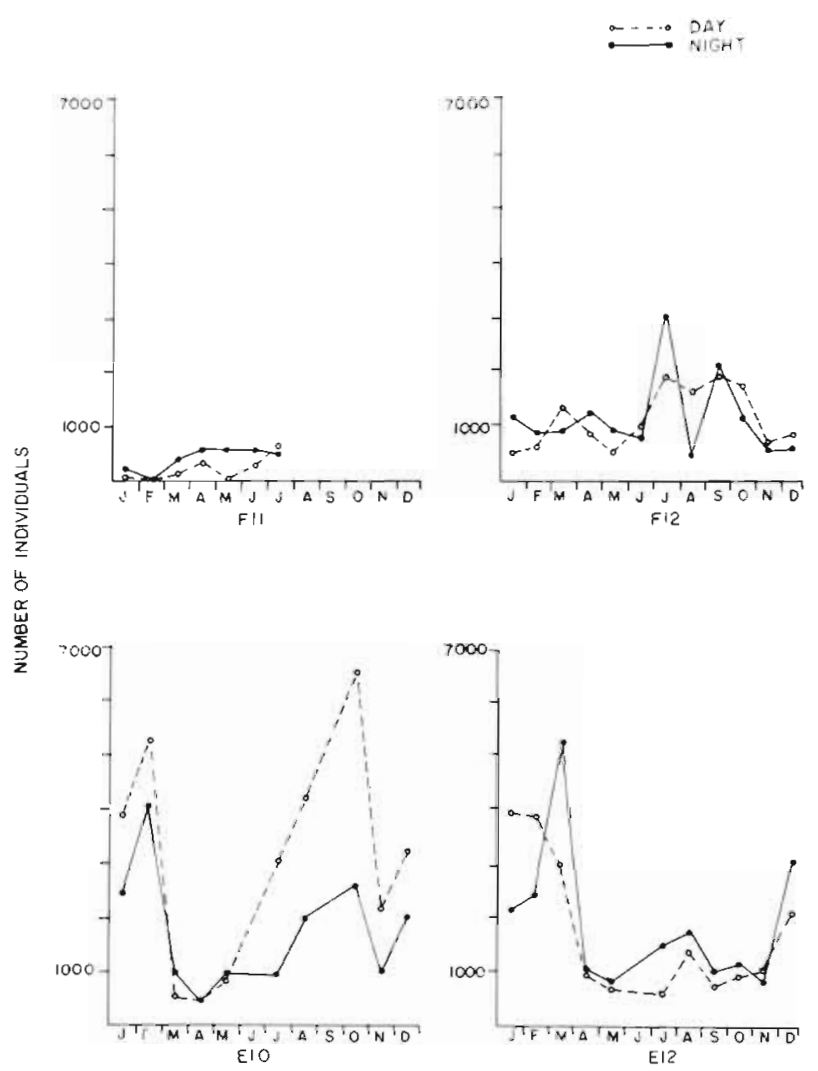

Fig. 5. Number of individuals collected over time by station

presentation of the structure of macroinvertebrate communities within Apalachee Bay. The relative abundances of several species that bury in the sediment during the day (Ambidexter symmetricus, Penaeus duorarum) would be seriously underestimated by an exclusively diurnal sampling program. Ambidexter symmetricus (a processid shrimp), for example, was only recently described (Manning and Chace, 1971), and has been considered uncommon in previous studies based on diurnal sampling (Saloman, 1979; Dugan, 1980). In the present study, however, A. symmetricus was the 8 th most abundant species in nocturnal samples, and ranked 11 th (of 95 species) in overall abundance because of the large numbers of individuals taken at night. Only 52 individuals $1.07 \%$ of the total diurnal catch) were taken in diurnal samples, while 3,654 individuals $15.04 \%$ of the total nocturnal catch) were collected at night (Greening, 1980). The diurnal samples would indicate that $A$. symmetricus is an uncommon species in Apalachee Bay; only with the addition of nocturnal sampling does the actual abundance of this species become apparent. The commercially important pink shrimp Penaeus duorarum has a similar pattern of abundance. $P$. duorarum comprised only $3.72 \%$ of the total day catch, but made up $12.25 \%$ of the night catch. The pink shrimp is one of the larger invertebrate species found in grassbeds, and appears to be an important predator of smaller invertebrates (Farfante, 1969; K. Leber, pers, comm.). Underestimated abundances (and consequently low biomass estimates) of $P$. duorarum obtained from diurnal sampling could seriously bias trophic analyses, as well as other areas of research in which biomass is an important factor. Because of the day/night changes in numerical abundances of these and other species, the relative abundance distribution of the sampled community changes with time of sampling. In many areas
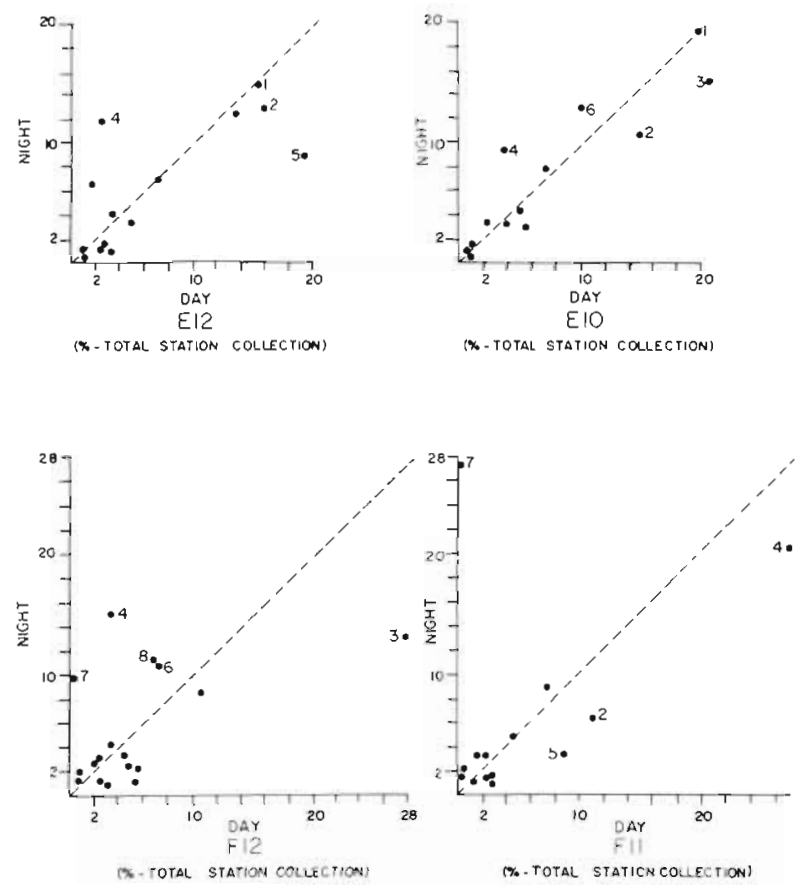

Fig. 6. Relative abundance day vs. night (summed over all dates) for those species comprising more than $1 \%$ of the total number of individuals collected at each station. Dotted line indicates equal diurnal/nocturnal relative abundance. (1) Hippolyte zostericola; (2) Pagurus bonairensis; (3) Anachis avara; (4) Penaeus duorarum; (5) Tozeuma carolinense; (6) Palaemon floridanus; (7) Ambidexter symmetricus; (8) Neopanope texana

of ecological research, accurate description of the structure of the subject community is vital (Virnstein, 1978). Trophic analyses, population dynamics, and the examination of inter- and intraspecific interactions require good representation of abundances, biomass, and relative abundance distributions. Clearly, for these and other areas of ecological study, both diurnal and nocturnal epibenthic collections are essential prerequisites for the development of testable hypotheses.

Habitat differences at each of the 4 stations appeared to influence the degree of variation between the sampled day and night communities. Significant differences (in numerical abundance) existed between diur- 
nal and nocturnal collections at 3 of the 4 stations sampled. At Station F12, no significant difference in the number of individuals collected was observed between day and night samples. Station E10 had a higher number of individuals collected during the day, while at Stations F11 and E12 significantly higher

Table 3. Species comprising more than $1 \%$ of the total number of individuals. Station rank in parentheses

\begin{tabular}{|c|c|c|c|}
\hline & Crustacea & Mollusca & Echinodermata \\
\hline \multicolumn{4}{|l|}{ Fenholloway 11} \\
\hline Day & - & - & - \\
\hline Night & $\begin{array}{l}\text { Ambidexter symmetricus (2) } \\
\text { Neopanope texana ( } 3 \text { ) } \\
\text { Callinectes sapidus (7) } \\
\text { Portunus gibbesi (8) }\end{array}$ & - & - \\
\hline Both day and night & $\begin{array}{l}\text { Penaeus duorarum (1) } \\
\text { Pagurus bonairensis (4) } \\
\text { Tozeuma carolinense (5) } \\
\text { Palaemon floridanus }(6) \\
\text { Pagurus pollicaris (9) } \\
\text { Periclimenes longicaudatus (11) } \\
\text { Neopanope packardii (12) } \\
\text { Libinia dubia (14) } \\
\text { Epialtus dilatatus (17) }\end{array}$ & $\begin{array}{l}\text { Nassarius vibex (13) } \\
\text { Argopectin irradians (15) } \\
\text { Anachis avara }\end{array}$ & Ophioderma brevispinum $(10)$ \\
\hline \multicolumn{4}{|l|}{ Fenholloway 12} \\
\hline Day & $\begin{array}{l}\text { Tozeuma carolinense (10) } \\
\text { Thor dobkini (15) }\end{array}$ & Anachis avara (1) & Ophioderma brevispinum (11) \\
\hline Night & $\begin{array}{l}\text { Penaeus duorarum (5) } \\
\text { Ambidexter symmetricus (6) } \\
\text { Alpheus normanni }(18)\end{array}$ & - & - \\
\hline Both day and night & $\begin{array}{l}\text { Pagurus bonairensis (2) } \\
\text { Neopanope texana (3) } \\
\text { Palaemon floridanus (4) } \\
\text { Hippolyte zostericola (7) } \\
\text { Periclimenes longicaudatus (8) } \\
\text { Neopanope packardii (9) } \\
\text { Libina dubia (12) } \\
\text { Epialtus dilatatus (17) }\end{array}$ & $\begin{array}{l}\text { Turbo castanea (13) } \\
\text { Argopectin irradians (14) } \\
\text { Columbella rusticoides (16) }\end{array}$ & - \\
\hline \multicolumn{4}{|l|}{ Econfina 10} \\
\hline Day & $\begin{array}{l}\text { Hippolyte zostericola (1) } \\
\text { Pagurus bonairensis (3) } \\
\text { Periclimenes longicaudatus (7) } \\
\text { Thor dobkini (9) } \\
\text { Palaemonetes intermedius (12) }\end{array}$ & $\begin{array}{l}\text { Anachis avara (2) } \\
\text { Urosalpinx perrugata (8) } \\
\text { Argopectin irradians (13) }\end{array}$ & - \\
\hline Night & Penaeus duorarum & - & - \\
\hline Both day and night & $\begin{array}{l}\text { Palaemon floridanus (4) } \\
\text { Neopanope texana (5) } \\
\text { Alpheus normanni (4) }\end{array}$ & Nassarius vibex (10) & - \\
\hline \multicolumn{4}{|l|}{ Econfina 12} \\
\hline Night & $\begin{array}{l}\text { Penaeus duorarum (5) } \\
\text { Ambidexter symmetricus (12) } \\
\text { Alpheus normanni (14) } \\
\text { Neopanope texana (15) }\end{array}$ & $\begin{array}{l}\text { Turbo castanea }(7) \\
\text { Argopectin irradians (9) }\end{array}$ & - \\
\hline Both day and night & $\begin{array}{l}\text { Hippolyte zostericola (1) } \\
\text { Pagurus bonairensis }(2) \\
\text { Periclimenes longicaudatus (4) } \\
\text { Thor dobkini }(6) \\
\text { Latreutes fucorum (16) }\end{array}$ & $\begin{array}{l}\text { Modulus modulus ( } 8) \\
\text { Columbella resticoides (10) } \\
\text { Cerithium muscarum (13) }\end{array}$ & Echinaster sp. A (11) \\
\hline
\end{tabular}


numbers of individuals were taken in nocturnal collections. The high volume of red algae (Digenia simplex, Gracilaria verrucosa, $G$. folifera, and Laurencia poitel) consistently taken at Stations E10 and F12 is a possible explanation for these day/night station differences (Fig. 2). Clumps of red algae often contain extremely large numbers of organisms in Apalachee Bay, including negatively phototactic species that find diurnal refuge between the thick branches (Hooks et al., 1976). Nocturnally active macroinvertebrates that take refuge in the red algae during the day would be indiscriminately caught both day and night by the epibenthic crab scrape. Some species (the xanthid crab Neopanope texana and the alpheid shrimp Alpheus normannl) were more abundant in nocturnal collections at stations without red algae (E12, F11). However, they were collected in approximately equal numbers diurnally and nocturnally at stations with red algae (Table 3), suggesting that these organisms find diurnal refuge in red algae when it is available. At those stations with little or no red algae, most of the nocturnally active macroinvertebrates appear to be buried in the sediment during the day (K. Leber, pers. comm.), thus escaping the scrape.

Both red algae clumps and dense vegetation may affect the degree of habitat complexity within grassbeds. Heck and Wetstone (1977) found that aboveground plant biomass was significantly correlated with both invertebrate species number and abundance and appeared to be a reasonable measure of habitat complexity for tropical seagrass beds. Red algae aggregations are thought to increase habitat complexity further in sub-tropical seagrass meadows (Hooks et al., 1976; Thorhaug and Roessler, 1977; Coen et al., 1981; Stoner and Livingston, 1980). In the present study, similar associations with macrophyte biomass and red algae volume were observed for abundances, but not for species richness. The stations with highest macrophyte biomass (E12, E10) had the largest number of individuals collected both day and night. Station F11 (with lowest macrophyte biomass and little red algae volume) had the lowest number of individuals collected (Fig. 5). Based on habitat complexity as defined by plant biomass and red algae volume, one would expect Stations E12 and E10 to have the highest species richness and Station F11 to have a very low number of species collected. However, Station E10 had the lowest total number of species collected (49), and Station F12 (medium macrophyte biomass and red algae volume) had the greatest species richness (81). Stations F11 and E12 had intermediate values (66 and 70 , respectively). We believe that the large number of invertebrate species collected at F12 was the result of periodic influxes of large sponges (containing sponge-associated animals) that did not occur at the other stations.
Station F11 is located at the edge of an oyster reef, and many of the species collected from this station were osyter-shell associated organisms found exclusively at F11. The different types of habitat complexity provided by the oyster reef and sponges may increase the diversity of available living areas. Higher numbers of species were collected at these stations than would be predicted by plant biomass and red algae volume alone. Further analyses of the influence of these different types of habitat complexity on the sampled communities is presently being conducted (Greening, unpubl.).

Increased habitat complexity appears to be associated with increased food availability, living space, and protection from predators (Heck and Wetstone, 1977). Refuge from fish predators may be of primary importance for potential invertebrate prey in grassbeds (Vince et al., 1976; Coen et al., 1981; Stoner, 1979; Ryan, 1981). Coen et al. (in a laboratory study) found that palaemonid shrimp could effectively escape predation by taking refuge in available red algae clumps. When crowded, those individuals pushed to the edges or out of the red algae were quickly eaten by the predator (Lagodon rhomboides). Stoner (1979) found selection of prey species by young pinfish (L. rhomboides) on amphipod crustaceans to be mediated by macrophyte biomass in Apalachee Bay. With increasingly denser vegetation, some amphipod species appeared to be protected from predation by $L$. rhomboides. Stoner (1979) concluded that behavioral characteristics of the amphipods probably determine whether or not they are taken by pinfish in heavy vegetation.

Motile epibenthic invertebrates are the preferred prey of fishes inhabiting seagrass beds (Randall, 1967; Carr and Adams, 1973; Adams, 1976; Brook, 1978; Stoner 1979, 1980; Livingston, 1980; Ryan, 1981). Trophic studies of temperate and sub-tropical seagrass systems indicate the ichthyofauna are predominately diurnal feeders, and diumally feeding fishes may account for $70-97 \%$ of the fish species present (Adams, 1976; Ryan, 1981). Nocturnal activity of macroinvertebrates has been hypothesized as being a direct result of this diurnal fish predation pressure (Hobson, 1965; Hobson and Chess, 1976).

In Apalachee Bay, a project concurrent with the present study found that crustaceans appeared to be the preferred nocturnal prey of fishes that feed both day and night (Ryan, 1981). Seabass Centropristis melana, toad-fish Opsanus beta, spiny puffers Chilomycterus schoepfi, and both sand and sea trout Cynoscion arenarius and C. nebulosus, respectively exhibited a generalist feeding habit diurnally and specialized on crustaceans at night. Motile crustaceans also dominated the diets of nocturnally feeding silver 
perch Bairdiella chrysoura, white grunt Haemulon plumieri and threadfin Polydactylus octonemus, while their diurnal prey were fish and epifauna (Ryan, 1981). Two nocturnally active macroinvertebrate species in this study - Penaeus duorarum and Ambidexter symmetricus - were rarely eaten by diurnally active fishes, but constituted a major portion of the diet of fishes feeding at night (Ryan, 1981). These data suggest that nocturnally active macroinvertebrates tend to escape diurnally feeding fishes, while presenting a vulnerable target for fishes feeding at night.

Our results indicate that diurnal/nocturnal variations in epibenthic macroinvertebrate community structure are the result of both individual and species behavior and the physical structure of the sampled habitat. Further descriptive and experimental research should be based on an understanding of diel activity patterns and the differential effect of habitat structure on observed faunal abundance and activity.

Acknowledgements. We wish to thank G. Morrison, K. Leber, F. G. Lewis III, J. Ryan, A. Stoner, L. Abele, and D. Thistle for critical comments and suggestions on the manuscript. Many people helped with the field work (especially K. Leber), to whom we are most grateful. During the course of this study, the first author received support, in the form of grants issued to R. J. Livingston, from Florida Sea Grant and the Environmental Protection Agency.

\section{LITERATURE CITED}

Adams, S. M. (1976). Feeding ecology of eelgrass fish communities. Trans. Am. Fish. Soc. 105: 514-519

Brook, I. M. (1978). Comparative macrofaunal abundance in turtle grass (Thalassia testudinum) communities in south Florida characterized by high blade density. Bull. mar. Sci. 28: 212-217

Carr, W. E. S., Adams, C. A. (1973). Food habits of juvenile marine fishes occupying seagrass beds in the estuarine zone near Crystal River, Florida. Trans. Am. Fish. Soc. 102: $511-540$

Coen, L. D., Heck, K. L., Jr., Abele, L. G. (1981). Experiments on competition and predation among shrimps of seagrass meadows. Ecology 62: 1484-1493

Dragovich, A., Kelly, J. A., Jr. (1964). Ecological observations of macroinvertebrates in Tampa Bay, Florida, 1961-1962. Bull. mar Sci. Gulf Caribb. 14: 74-102

Dugan, P. J. (1980). Long-term population changes of epibenthic macroinvertebrates in Apalachee Bay, Florida. M. Sc thesis, Florida State University

Dugas, R. J. (1975). Variation in day-night trawl catches in Vermillion Bay, Louisiana. Louisiana Wildlife and Fisheries Commission Tech. Bull. 14.

Ebeling, A., Bray, R. N. (1976). Day versus night activity of reef fishes in a kelp forest off Santa Barbara, California. Fish. Bull., U.S. 74: 703-717

Farfante, I. P. (1969). Western Atlantic shrimps of the genus Penaeus. Fish. Bull. Fish Wildl. Serv. U.S. 67 (3): 461-591

Fuss, C. M., Jr. (1964). Observations on burrowing behavior of the pink shrimp, Penaeus duorarum Burkenroad. Bull. mar. Sci. Gulf Caribb. 14: 62-73
Fuss, C. M., Ogren, L. H. (1966). Factors affecting activity and burrowing habits of the pink shrimp. Penaeus duorarum Burkenroad. Biol. Bull. mar biol. Lab., Woods Hole 130: 170-191

Greening, H. S. (1980). Seasonal and diel variations in the structure of macroinvertebrate communities: Apalachee Bay, Florida. M. Sc thesis, Florida State University

Heck, K. L., Jr (1973). The impact of pulp mill effluents on species assemblages of epibenthic invertebrates in Apalachee Bay, Florida. M. Sc. thesis, Florida State University

Heck, K. L., Jr. (1977). Comparative species richness, composition, and abundance of invertebrates in Caribbean seagrass (Thalassia testudinum) meadows (Panama). Mar. Biol. 41. 335-348

Heck, K. L., Jr., Wetstone, G. S. (1977). Habitat complexity and invertebrate species richness and abundance in tropical seagrass meadows. J. Biogeogr. 4: 135-142

Hobson, E. S. (1965). Diurnal-nocturnal activity of some inshore fishes in the Gulf of California. Copeia 1965 (3): 291-302

Hobson, E. S. (1973). Diel feeding migrations in tropical reef fishes. Helgoländer wiss. Meeresunters. 24: 351-370

Hobson, E. S. (1975). Feeding patterns among tropical reef fishes. Am. Sci. 63: 382-392

Hobson, E. S., Chess, J. R. (1976). Trophic interactions among fishes and zooplankters near shore at Santa Catalina Island, California. Fish. Bull, U.S. 74:567-598

Hoese, H. D., Jones, R. S. (1963). Seasonality of larger animals in a Texas turtle grass community. Publ. Inst. mar Sci. Tex. 9:37-47

Hooks, T A. (1973). An analysis and comparison of the benthic invertebrate communities in the Fenholloway and Econfina estuaries of Apalachee Bay, Florida. M. Sc. thesis, Florida State University

Hooks, T A., Heck, K. L., Jr., Livingston, R. J. (1976). An inshore marine invertebrate community: structure and habitat associations in the northeastern Gulf of Mexico. Bull. mar. Sci. 26: 99-109

Hughes, D. A. (1968). Factors controlling the emergence of pink shrimp (Penaeus duorarum) from the substrate. Biol. Bull. mar. biol. Lab., Woods Hole 134: 48-59

Kikuchi, T (1966). An ecological study on anımal communities of the Zostera marina belt in Tomioka Bay. Amakusa, Kyushu. Publ. from Amakusa Mar Biol. Lab., Kyushu University 1 (1)

Kikuchi, T., Pérès, J. M. (1977). Consumer ecology of seagrass beds. In: McRoy, C. P., Helfferich, C. (eds.) Seagrass ecosystem, a scientific perspective. Marcel Dekker, Inc., Leiden, pp. 147-194

Livingston, R. J. (1975). Impact of kraft pulp-mill effluents on estuarine and coastal fishes in Apalachee Bay, Florida, USA. Mar Biol. 32: 19-48

Livingston, R. J. (1976). Diurnal and seasonal fluctuations of organisms in a north Florida estuary. Estuar coast. mar Sci. $4: 373-400$

Livingston, R. J. (1977a). Time as a factor in biomonitoring estuarine systems with reference to benthic macrophyte and epibenthic fishes and invertebrates. Biol. Monit. of Water and Effluent Quality, ASTM STP 607: 212-234

Livingston, R. J. (1977b). Recovery of the Fenholloway drainage system: analysis of water quality, benthic macrophytes and fishes in Apalachee Bay (1971-1976) following implementation of a waste control program. Final Report, Buckeye Cellulose Corporation

Livingston, R. J. (1980). Community structure and trophic interactions in a coastal seagrass system. Evaluation of 
short- and long-term variability, water quality, and biological response. Final report to U.S. Environmental Protection Agency

Livingston, R. J., Lloyd, R. S., Zimmerman, M. S. (1976). Determination of adequate sample size for collections of benthic macrophytes in polluted and unpolluted coastal areas. Bull. mar Sci. 26: 569-575

McNaughton, S. J. (1968). Structure and function in California grasslands. Ecology 49: 962-972

Manning, R. B., F. A. Chace, Jr. (1971). Shrimps of the family Processidae (Crustacea, Decapoda, Caridea) from the northwestern Atlantic. Smithson. Contrib. to Zool. 89: $1-41$

Pielou, E. C. (1977). Mathematical ecology, (2nd. ed.), Wiley, New York

Randall, J. (1967). Food habits of reef fishes of the West Indies. Studies Trop. Oceanography Miami 5: 665-847

Reynolds, W. S., Casterlin, M. E. (1979). Diel activity of the pink shrimp, Penaeus duorarum. Hydrobiologia 66: 223-226

Ryan, J. R. (1981). Trophic analysis of nocturnal fishes in seagrass beds in Apalachee Bay, Florida. M. Sc. thesis, Florida State University

Saloman, C. H. (1979). New records of caridean shrimps (Decapoda, Caridea) from the nearshore area of Panama City Beach, Florida, USA. Crustaceana 5 (Suppl.): 147-152

Saville, T. (1966). A study of estuarine pollution problems on a small unpolluted estuary and a small polluted estuary in Florida. Engng Prog. Univ. Fla 125: 1-202

Segal, E. (1970). Light: Animals: Invertebrates. In: Kinne, O. (ed.) Marine ecology, Vol. I, Environmental factors, Part 1. Wiley, London, pp. 159-211

Starck, W. A., II, Davis, W. P. (1966). Night habits of fishes of Alligator Reef, Florida. Ichthyalogica, Aquarium J. 38: 313-356

Stoner, A. W. (1979). Species specific predation on amphipod
Crustacea by pinfish (Lagodon rhomboides): mediation by macrophyte standing crop. Mar. Biol. 55: 201-207

Stoner, A. W. (1980). The feeding ecology of the Lagodon rhomboides (Pisces: Sparidae): variation and functional responses. Fish. Bull, U.S. 78: 337-352

Stoner, A. W., Livingston, R. J. (1980). Distribution ecology and food habits of the banded blenny, Paraclinus fasciatus: an inhabitant of a mobile community. Mar. Biol. 56: 239-246

Thorhaug, A., Roessler, M. S. (1977). Seagrass community dynamics in a subtropical esturine lagoon. Aquaculture 12: $253-277$

Vince, S. I., Valiela, I., Backus, N., Teal, J. (1976). Predation by the salt marsh killifish Fundulus heteroclitus (L.) in relation to prey size and habitat structure; consequences of prey distribution and abundance. J. exp. mar. Biol. Ecol. 23: $255-266$

Virnstein, R. W. (1978). Predator caging experiments in soft sediments: caution advised. Estuarine Interactions 1978: 261-273

Zimmerman, M. S. (1974). A comparison of the benthic macrophytes of a polluted drainage system (Fenholloway River) with an unpolluted drainage system (Econfina River). M. Sc. thesis, Florida State University

Zimmerman, M. S., Livingston, R. J. (1976a). Effects of kraftmill effluents on benthic marophyte assemblages in a shallow-bay system (Apalachee Bay, North Florida, U.S.A.). Mar. Biol. 34: 297-312

Zimmerman, M. S., Livingston, R. J. (1976b). Seasonality and physico-chemical ranges of benthic macrophytes from a north Florida estuary (Apalachee Bay). Contr. mar. Sci. Univ. Texas 20: $34-45$

Zimmerman, M. S., Livingston, R. J. (1979). Dominance and distribution of benthic macrophyte assemblages in a north Florida estuary (Apalachee Bay, Florida). Bull. mar. Sci. 29: $27-40$ 